\title{
Investasi Cerdas di Tengah Pandemi: Webinar Otoritas Jasa Keuangan (OJK)
}

\author{
Dewa Ayu Oki Astarini ${ }^{1}$, Anthony Anggrawan ${ }^{2}$, R. Ayu Ida Aryani ${ }^{3}$, Ikang Murapi ${ }^{4}$ \\ Astarini.oki@universitasbumigora.ac.id ${ }^{1}$, \\ anthony.anggrawan@universitasbumigora.ac.id ${ }^{2}$, \\ ayu.aryani@universitasbumigora.ac.id ${ }^{3}$, ikangmurapi11@universitasbumigora.ac.id ${ }^{4}$ \\ 1,2,3 Universitas Bumigora
}

\begin{abstract}
Article History:
Received: 12-07-2021

Revised: 22-07-2021

Accepted: 26-07-2021
\end{abstract}

\begin{abstract}
This webinar with OJK aims to educate the members about smart investments that can be done in the midst of the covid 19 pandemic in the Indonesian Capital Market and analysis that investors need to do before starting to invest. This is also one of the way to motivate millennials students to have a paradigm of investment society. This devotion was conducted in the form of a webinar event "smart investment in the middle of the pandemic" with participants of Bumigora University students and lecturer. The webinar aims to add insight into how to invest in stocks, indicators to consider and strategies for stock investments that generate income with controllable risks. A simulation of how to utilize the existing technology on smartphones for ease in investing through investment applications in play store is given in this event.
\end{abstract}

Keywords: smart investments, covid 19 pandemic, webinar OJK

\section{Pendahuluan}

Pasar modal merupakan tempat pertemuan antara pihak yang memerlukan modal dan pihak yang kelebihan modal. Melalui pasar modal, terjadilah interaksi antara investor yang memiliki kelebihan dana dan perusahaan yang memerlukan dana untuk pengembangan aktivitas perusahaannya. Peran pasar modal semakin vital ketika perekonomian semakin berkembang. Terjadi simbiosis mutualisme antara investor yang menginginkan dananya berkembang namun tidak memiliki usaha, dan pengusaha yang memerlukan suntikan dana untuk pengembangan usahanya (Fahmi, 2015). Investor yang menginvestasikan uangnya pada perusahaan akan mendapatkan deviden atau pembagiandari laba yang dihasilkan perusahaan tersebut.

Perkembangan teknologi dan informasi yang begitu pesat mendukung-perubahan dalam ilmu investasi untuk menyesuaikan dengan kondisi terkini. Saat ini, keputusan dan tindakan investasi tidak lagi serumit dulu, ketika kedua belah pihak harus hadir dan menyetujuinya. Sekarang, kedua belah pihak sudah dapat menyetujuinya cukup dengan menggunakan jaringan perangkat lunak seperti internet (Fahmi, 2015). Meski teknologi sangat membantu dalam penyelesaian berbagai permasalahan, namun kita juga perlu ingat bahwa saat ini kejahatan dalam bidang teknologi mengalami peningkatan yang sangat serius (Fahmi, 2015). Untuk mengurangi terjadinya tindakan kejahatan dalam bidang teknologi terkait dengan investasi tersebut, pentingnya edukasi dan sosialisasi investasi 
yang baik dan benar saat ini menjadi kebutuhan yang mutlak.

Tahun 2020 merupakan tahun yang menantang bagi perekonomian dunia termasuk Indonesia, pandemi covid 19 mengguncang ekonomi berbagai kebijakan dirilis untuk menjaga industru di pasar modal agar bertahan di tengah pandemic diantaranya rapat umum pemegang saham secara elektronik, relaksasi penyampaian, masa berlaku laporan keuangan dan insentif dan potongan biaya oleh safe regulatory organitation (SRO). Pandemi COVID-19 tidak menyurutkan langkah pengembangan pasar modal dan apresiasi yang dilakukan oleh PT Bursa Efek Indonesia (BEI) dengan dukungan seluruh stakeholders pasar modal, khususnya Anggota Bursa dan Perguruan Tinggi (metrotvnews.com, 2020). Hal tersebut dibuktikan perkembangan pasar modal Indonesia walaupun IHSG sempat berada dititik terendah 3.937 namun bangkit lagi dengan trend yang terus positif hingga berada di atas level 6.000. Kinerja pasar modal tersebut tentunya menjadikan investasi saham sebagai salah satu investasi cerdas yang dapat dilakukan saat pandemi covid 19. Hal tersebut juga didukung dengan perkembangan teknologi dan informasi yang begitu pesat mendukung perubahan dalam ilmu investasi untuk menyesuaikan dengan kondisi terkini.

Transaksi di pasar modal dan kemudahan dalam investasi saham dengan menggunakan smartphone sudah umum dilakukan oleh negara maju dan untuk negara berkembang sendiri masih didominasi oleh masyarakat yang ada di kota besar seperti Jakarta dan Surabaya. Untuk daerah seperti Nusa Tenggara Barat paradigma masyarakat masih didominasi oleh saving society dibandingkaan dengan investment society, dikarenakan kurangnya edukasi mengenai keuntungan dan ketakutan terhadap resiko dari investasi. Agar paradigma investment society lebih mendominasi diperlukan peran generasi millennial daerah untuk melek investasi dengan meningkatan wawasan melalui edukasi akan pentingnya investasi. Edukasi tersebut memberikan informasi dan arahan bahwa investasi tidak hanya bisa dilakukan oleh investor dengan dana yang besar tapi masyarakat biasa terutama mahasiswa dengan dana yang terbatas. Berbagai macam investasi dapat dilakukan mulai dari investasi emas sampai dengan investasi saham. Menariknya saat ini smartphone memberikan kemudahan untuk mulai berinvestasi saham dengan mengunduh aplikasi investasi seperti bareksa, bibit, simasi equity dan aplikasi investasi lainya yang telah terdaftar di OJK.

Investasi saham adalah salah satu investasi yang akan memberikan potensi keuntungan dengan resiko yang dapat dikontrol. Pengabdian ini juga ingin memberikan pencerahan bahwa transaksi saham bukanlah spekulasi seperti halnya pada judi, namun pemilihan saham berdasarkan pada pertimbangan yang jelas, baik dari segi fundamental, teknikal maupun strategi masuk dan keluar ( beli dan jual) yang menekankan kepada 
kestabilan psikologis. Kestabilan psikologis adalah penentu kesuksesan bertransaksi saham selain pengalaman dan ilmu tentang pasar modal (Ady, 2014). Kinerja investasi saham dapat dibedakan berdasarkan usia, pendidikan, pengalaman, karakter, gender, budaya dan nilai-nilai yang diyakini oleh investor(Ady, 2015). Mahasiswa mengungkapkan ketertarikan yang kuat untuk untuk mengetahui dan mengenal investasi di pasar modal.

Dari penjelasan diatas maka dapat dirincikan permasalah yang dialami mitra yaitu :

1) Keadaan pasar modal di tengah pandemi covid 19 menjadi kesempatan bagi mahasiswa untuk mulai belajar investasi saham dikarenakan banyak harga saham yang diskon. Kesempatan ini belum dimanfaatkan dengan maksimal oleh mahasiswa.

2) Pola pikir masyarakat saat ini dalam mengelola dana simpanan masih sebatas menabung tidak dengan investasi. Hal tersebut dikarenakan kurangnya edukasi mengenai pentingnya investasi.

3) Tantangan untuk dapat memanfaatkan waktu luang yang dimiliki sebagai mahasiwa dan uang saku yang diberikan oleh orang tua agar dapat menghasilkan pendapatan. Dalam hal ini mahasiswa harus cerdas dalam menyusun strategi untuk menghasilkan pendapatan dari investasi saham dengan didukung ilmu yang mereka dapatkan saat kuliah.

4) Sebagai mahasiswa yang saat ini termasuk dalam golongan generasi milenal dan memiliki smartphone dengan akses digital yang mendukung, jumlah mahasiswa yang melek akan investasi masih sangat kurang. Rendahnya peran mahasiswa untuk investasi saham disebabkan paradigma mahasiswa yang masih menganggap investasi saham membutuhkan dana yg besar dan takut akan resiko yang tinggi.

\section{Metode}

Pengabdian ini dilaksanakan dengan mengadakan webinar yang berjudul "investasi cerdas di tengah pandemic" tanggal 15 April 2020 dengan menggunakan media zoom disesuaikan dengan kondisi di tengah pandemic covid 19. Peserta webinar adalah mahasiswa universitas Bumigora. Metode yang digunakan dalam pelatihan ini dapat dilihat pada diagram 1: 


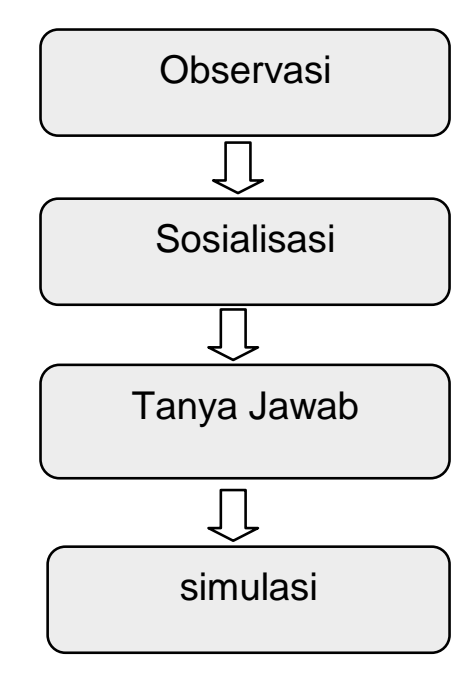

Diagram 1: Metode Kegiatan Pengabdian pada Masyarakat

1) Tahap pertama yang dilakukan dalam penelitian ini adalah observasi terkait dengan target dari peserta. Target perserta dalam kegiatan webinar ini adalah mahasiswa Universitas Bumigora yang tertarik untuk belajar investasi saham.

2) Sosialisasi dengan memberikan edukasi kepada mahasiswa tentang:

a. Manajemen keuangan, bagaimana mengelola dana atau asset agar menghasilkan passive income.

b. Manfaat investasi untuk masa depan karena dapat meningkatkan nilai kekayaan tanpa takut terkena dampak inflasi.

c. Bagaimana mengontrol resiko yang terjadi dengan memantau dari kondisi makro yang berakibat pada perubahan harga saham salah satunya adalah pasar modal pada saat pandemic covid 19 dan fundamental perusahaan untuk memutuskan pembelian saham.

d. Pentingnya melakukan analisis. Ada dua analisis yang digunakan dalam kegiatan ini yaitu analisis fundamental dan analisis teknikal. Analisis Fundamental; makro Ekonomi dan Industri Terdapat tiga tahap pendekatan Top Down, yaitu : 1. Analisis Ekonomi, digunakan untuk menentukan bobot ekuitas dalam portofolio. 2. Analisis Industri, digunakan untuk menentukan bobot berbagai industri dalam portofolio, karena berbagai faktor, yaitu : (a) Return \& risiko antar industri berbeda (b) Return suatu industri berubah antar waktu, tetapi risiko tetap (c) Return perusahaan dalam industri sama, bisa sangat berbeda (d) Memberikan fondasi untuk analisis perusahaan (Jones, 1998). Analisis Teknikal; analisis ini merupakan upaya untuk memperkirakan 
harga saham dengan mengamati perubahan harganya di waktu yang lalu. Analisis tersebut mengasumsikan (1) bahwa harga saham mencerminkan informasi yang relevan, (2) bahwa informasi tersebut ditunjukkan oleh perubahan harga di waktu yang lalu, dan (3) karenanya perubahan harga saham akan mempunyai pola tertentu, dan pola tersebut akan berulang, (Harianto, 1998)

3) Tanya jawab untuk memberikan kesempatan kepada mahasiswa terhadap materi yang belum dipahami.

4) Simulasi investasi saham memanfaatkan smartphone dengan menggunakan aplikasi investasi seperti bareksa dan bibit.

Adapun beberapa prosedur kerja yang dilakukan untuk mendukung metode pelaksanaan pengabdian kepada masyarakat. Pertama, mengundang salah satu pihak dari OJK sebagai nara sumber webinar. Kedua, mengundang seluruh mahasiswa Universitas Bumigora dengan menyebarkan flyer melalui social media dan whatsap. Ketiga, memberikan link google form data peserta kepada mahasiswa yang tertarik untuk mengikuti webinar. Keempat, mendata kembali peserta yang sudah mengisi data di google form kemudian memberikan link zoom webinar melalui email setiap peserta. Kelima, pemberian edukasi dan materi mengenai "Investasi Cerdas Di Tengah Pandemic" dengan narasumber dari dosen prosi S1 Akuntansi Dewa Ayu Oki Astarini, M.Ak dan dari pihak OJK Agus Muntholib Analisis Senior Deputi Direktur Pengembangan Sistem Informasi Pasar Modal. Keenam, evaluasi Penyajian data dan menganalisis hasil edukasi. Ketujuh, deskripsi dan pembahasan hasil edukasi pasar modal.

Dalam pengabdian ini diperlukan partisipasi dari mahasiswa yaitu berupa diwajibkan membawa barang dan merespon pertanyaan-pertanyaan. Setiap peserta diwajibkan membawa smartphone masing-masing dan mendownload aplikasi bibit atau bareksa. Beberapa peserta yang dapat menjawab pertanyaan akan mendapatkan tabungan saham senilai Rp.100.000 dan dapat langsung mempraktekan untuk pembelian saham

\section{Pembahasan}

Pelaksanaan webinar yang berjudul "Investasi Cerdas di Tengah Pandemi" sesuai dengan kondisi adanya wabah covid 19 yang berpengaruh terhadap harga saham di pasar modal. Banyak unit di pasar modal yang harganya turun dan hal tersebut banyak dimanfaatkan oleh para trader untuk membeli saham dikarenakan banyak harga saham yang "diskon", kesempatan tersebut menjadikan investasi saham menjadi investasi cerdas yang dilakukan saat pandemi. Webinar dilaksanakan pada tanggal 25 September 2020 pukul 14.00 wita bertempat di Universitas Bumigora dengan peserta sebagian besar berasal https://journal.universitasbumigora.ac.id/index.php/ADMA 
dari Fakultas Ekonomi dan Bisnis. Hal tersebut sesuai dengan data yang diisi oleh peserta melalui link google form yang diisi oleh peserta. Dari pengisian google form tersebut peserta akan mengisi data diri salah satunya adalah alamat email, yang nantinya link zoom webinar tersebut dibagikan melalui email masing-masing dari tiap peserta.

Pelaksanaan webinar tersebut diawali dengan pembukaan oleh dekan Fakultas Ekonomi dan Bisnis yaitu Ibu Dr. Titik Ceriyani Miswaty M.Pd dan kemudian dilanjutkan oleh pemateri awal yaitu Ibu Dewa Ayu Oki Astarini, M.Ak yang membahas mengenai pentingnya investasi. Kemudaian acara inti dilanjutkan oleh narasumber dari pihak OJK Bapak Agus Muntholib selaku analis senior deputi pasar modal OJK yang menyampaikan materi inti terkait investasi saham dan play store investasi saham yang sudah terdaftar di OJK yang mendukung untuk investor pemula. Dalam pelaksanaan webinar peserta sangat antusias, hal tersebut didukung dengan adanya interaksi langsung antara narsum atau pemateri dengan peserta. Webinar tersebut sangat menarik bagi mahasiswa dikarenakan adanya sesi tanya jawab, dan bagi peserta yang mampu menjawab akan mendapatkan uang untuk modal investasi saham senilai Rp. 100.000.

Tahap selanjutnya adalah simulasi setelah penyampaian materi yang mengedukasi para peserta mengenai investasi saham dan informasi terkait kondisi pasar modal di tengah pandemi covid 19. Selama pelaksanaan webinar berlangsung peserta berpartisipasi untuk dengan menggunakan smartphone masing-masing untuk mengunduh aplikasi bibit atau bareksa mengikuti simulasi yang diberikan oleh narasumber. Selama pelaksanaan simulasi tersebut sebagian besar peserta sudah paham bagaimana menggunakan aplikasi tersebut untuk investasi saham.

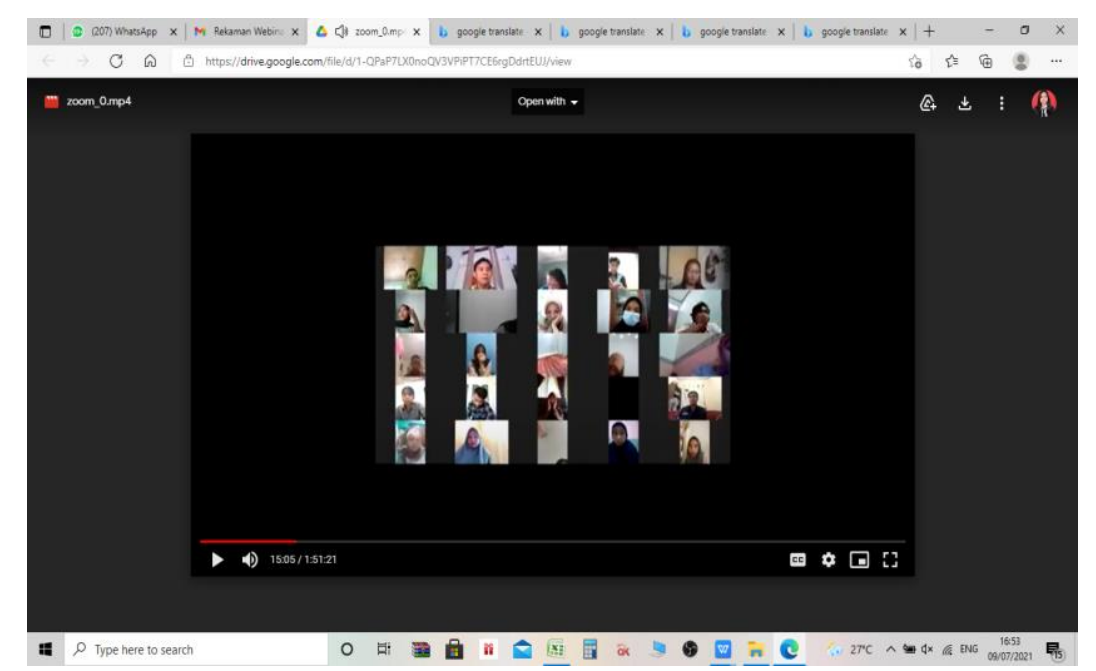

Gambar 1: Screen shoot pembukaan webinar melalui zoom meeting

Webinar "Investasi Cerdas di Tengah Pandemic" melalui zoom meeting dikuti oleh 105 peserta dari Mahasiswa dan Dosen Universitas Bumigora serta umum. Pada saat zoom https://journal.universitasbumigora.ac.id/index.php/ADMA 
meeting, kamera peserta dihidupkan dan diwajibkan untuk tidak menghidupkan mikrofon pada saat narasumber menyajikan materi. Namun pada saat interaksi, mahasiswa yang ingin bertanya, menjawab dan memberikan respon dari webinar tersebut dipersilahkan untuk menghidupkan kembali mikrofon.

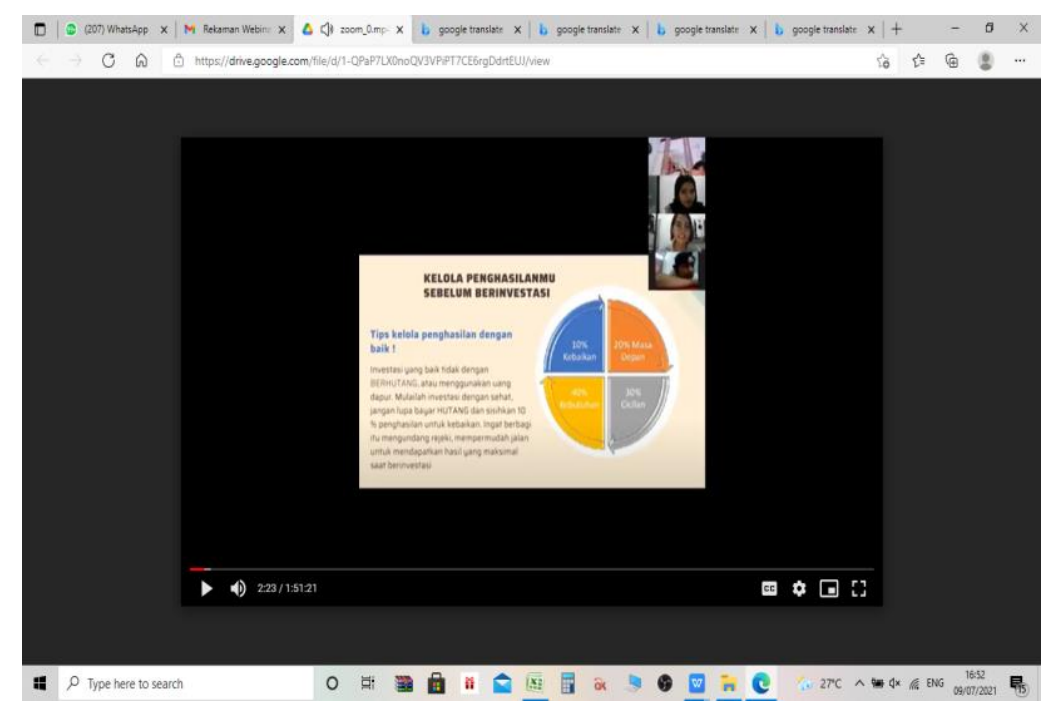

Gambar 2. Presentasi materi terkait pentingnya investasi di tengah pandemic Covid 19

Persentasi pertama disajikan oleh narasumber dari dosen Universitas Bumigora yaitu Ibu Dewa Ayu Oki Astarini, S.E, M. Ak. Materi yang disajikan membahas mengenai pentingnya memulai investasi dan mengubah paradigma dari saving society menjadi investement society. Dan hal yang penting untuk diperhatikan yaitu bagaimana memiliki manajemen keuangan yang baik. Mengelola penghasilan yang dimiliki pada porsi yang sesuai agar tidak konsumtif sehingga sebagian bisa dianggarkan untuk investasi.

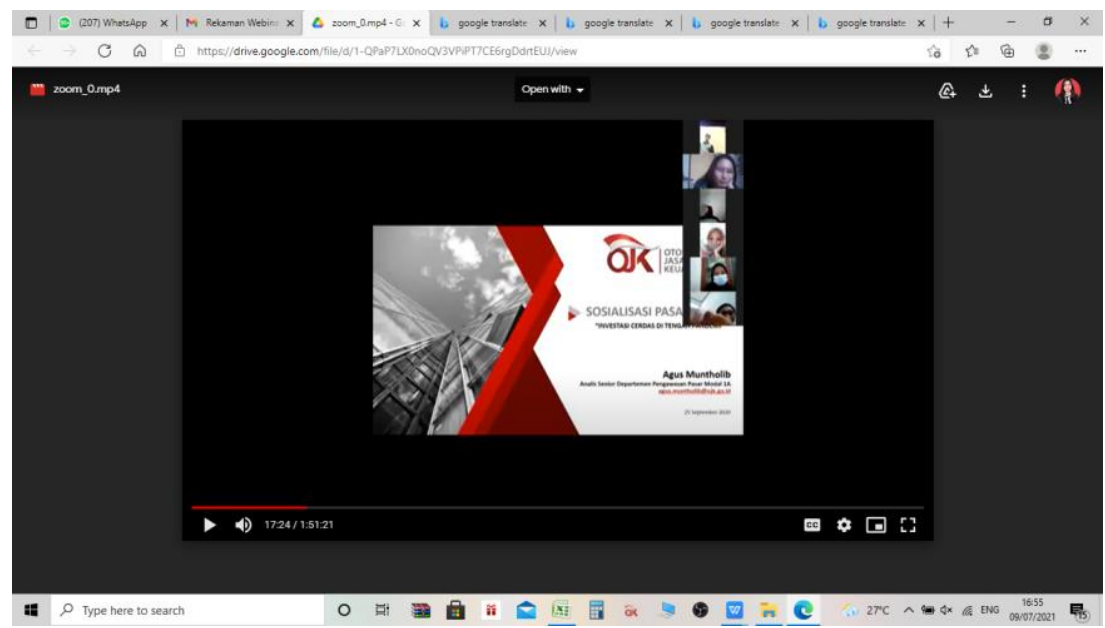

Gambar 3. Screenshoot presentasi narasumber dari Pihak OJK

Persentasi selanjutnya disajikan oleh narasumber dari OJK yaitu Bapak Agus Muntholib. Materi yang disajikan membahas mengenai sosialisai pasar modal. Narasumber 
memberikan edukasi terkait pasar modal dan bagaimana menghasilkan pasive income melalui investasi saham pada pasar modal.

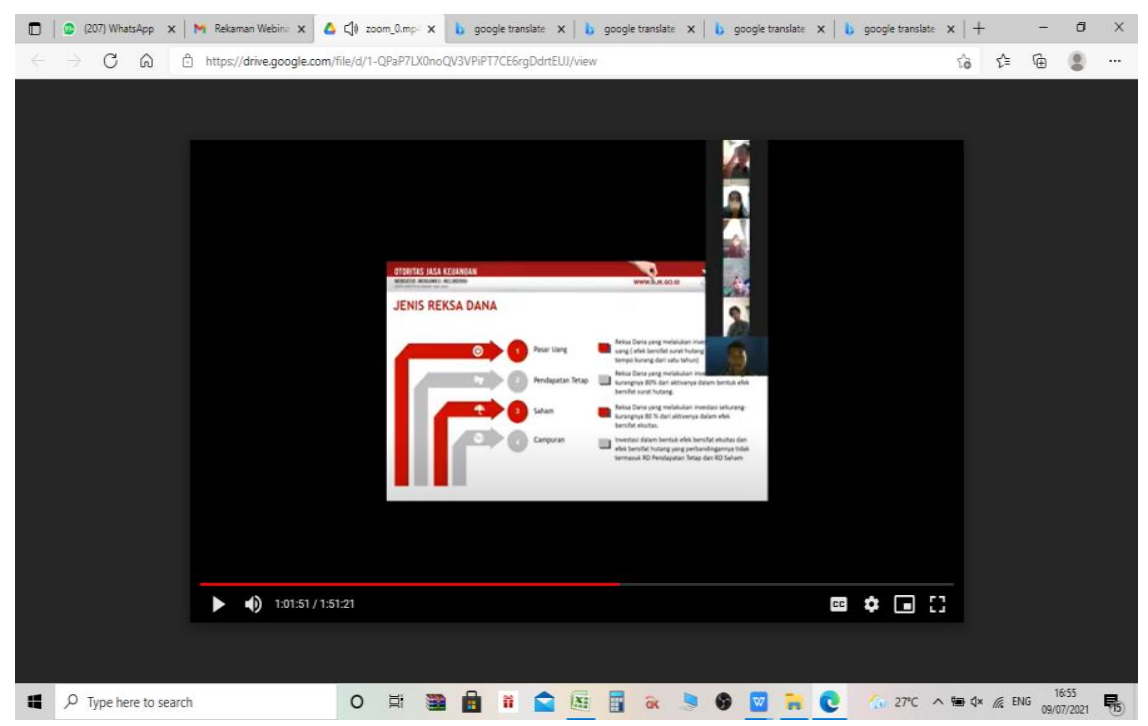

Gambar 4: Screenshoot interaksi antara peserta dengan narasumber dari pihak OJK.

Sesi selanjutnya adalah tanya jawab sebagai bentuk dari interaksi narasumber dengan peserta. Dalam sesi ini disajikan dalam bentuk games yang hadiahnya adalah tabungan saham senilai Rp.100.000 untuk empat orang peserta dari pihak OJK dan voucher belanja senilai Rp.100.000 untuk empat orang peserta dari prodi Akuntansi Universitas Bumigora. Para peserta sanggat antusias untuk dapat memenangkan games tersebut. Tidak hanya itu antusias peserta yang tertarik memulai investasi dengan manabung saham.

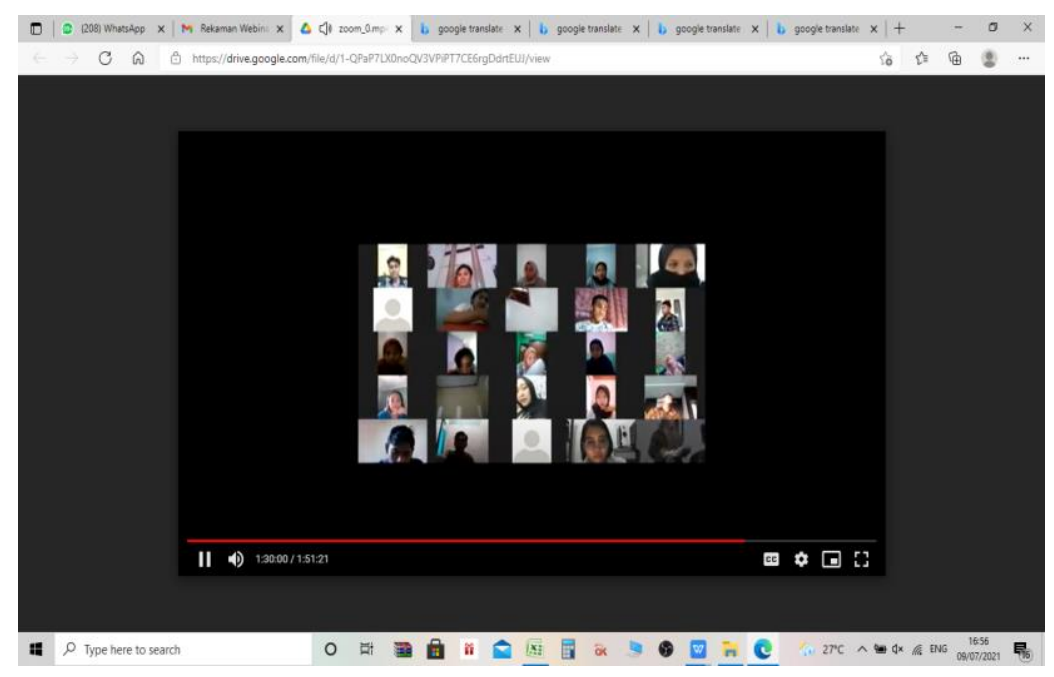

Gambar 5: Screenshoot foto bersama dengan mahasiswa pada saat penutupan zoom meeting.

Pada akhir acara webinar "Investasi Cerdas di Tengah Pandemic", para peserta dan nara sumber dari Universitas Bumigora dan OJK melakukan foto bersama secara virtual. Pada saat penutupan jumlah peserta yang masih aktif sampai akhir acara sebanyak 95 
orang dari 105 orang peserta. Berkurangnya jumlah peserta sebagian besar pada saat sesi games disebabkan ada beberapa peserta yang ijin untuk leave karena ada kegiatan lain yang harus diikuti.

\section{Kesimpulan}

Dari pembahasan yang sudah dipaparkan dapat diambil kesimpulan para peserta webinar "Investasi Cerdas di Tengah Pandemic" sangat antusias mengikuti kegiatan tersebut dilihat dari jumlah peserta sebagian besar tetap aktif yaitu dari awal acara ada 105 peserta dan pada saat penutupan 95 peserta, materi yang diberikan oleh narasumber diserap dengan baik oleh sebagian besar peserta terbukti dari antusias tanya jawab pada saat sesi games dan sekitar $20 \%$ dari jumlah peserta mengungkapkan keinginan untuk segera membuka rekening pada sekuritas yang di rekomendasikan OJK dan aplikasi investasi seperi Bareksa dan bibit.

\section{Ucapan Terima Kasih}

Ucapan terima kasih yang tak terhingga diberikan kepada Universitas Bumigora selaku pelindung dalam kegiatan pengabdian ini kami juga ucapkan terima kasih kepada Ketua LPPM beserta jajarannya yang telah memberikan dukungan dan bantuan dalam kegiatan ini sehingga pengabdian ini bisa berjalan dengan lancar dan dari pihak OJK atas kesedianya menjadi narasumber. Tidak lupa pula kami sampaikan apresiasi kepada mahasiswa Universitas Bumigora yang sudah antusias mengikuti webinar "Investasi Cerdas Di Tengah Pandemic".

\section{Daftar Pustaka}

Ady. (2014). Nilai-nilai Dibalik kestabilan Psikologis, Kunci Sukses berinvestasi (Studi pada Perilaku Investor di Bursa Efek Indonesia). Prosiding Seminar Nasional Simposium Riset Ekonomi VI, 321-334.

Ady. (2015). Manajemen Psikologi dalam Investasi Saham, Kajian Fenomenologi dalam Sentuhan Behavioral Finance. Edisi 1. Andi Offset, Yogyakarta.

Fahmi. (2015). Manajemen Investasi Edisi 2.

Harianto. (1998). Perangkat dan Teknik Analisis Investasi di Pasar Modal Indonesia. Edisi Pertama, PT. Bursa Efek Jakarta.

Jones. (1998). Investment, Analysis and Management,. Sixth Edition. John Wiley \& Son, Inc. USA. metrotvnews.com. (2020). Kinerja Pasar Modal Indonesia 2020. Retrieved from https://www.metrotvnews.com/play/bw6C59xx-kinerja-pasar-modal-indonesia-2020 
